\title{
Pengaruh Zona Jenuh Air Terhadap Kestabilan Lereng di Weninggalih, Kabupaten Bandung Barat
}

\author{
Moch Hilmi Zaenal Putra ${ }^{*}$, Rendy Dwi Kartiko², Prihadi Soemantidiredja ${ }^{2}$, \\ Imam Achmad Sadisun ${ }^{2}$, Adrin Tohari ${ }^{1}$
}

${ }^{1}$ Pusat Penelitian Geoteknologi, Lembaga Ilmu Pengetahuan Indonesia (LIPI), Bandung, 40135, Indonesia

${ }^{2}$ Fakultas Ilmu Teknologi dan Kebumian, Institut Teknologi Bandung (ITB), Bandung, 40132, Indonesia

\begin{abstract}
ABSTRAK Kejadian longsor dangkal di Desa Weninggalih mengakibatkan kerugian setiap tahunnya. Hal tersebut diakibatkan oleh salah satu budaya warga setempat yaitu membuat kolam ikan tanpa dilapisi lapisan kedap air sehingga diduga menjadi salah satu faktor penyebab menurunnya kestabilan lereng. Sebagai upaya untuk mengurangi risiko kerugian tersebut dibutuhkan pemahaman yang baik mengenai karakteristik longsor dan pengaruh keberadaan kolam ikan terhadap kondisi kestabilan lereng. Penelitian ini bertujuan untuk mengetahui tingkat kestabilan lereng dan pengaruh keberadaan kolam ikan untuk studi kasus di daerah Weninggalih. Metode yang digunakan dalam penelitian ini meliputi pemetaan geologi, pemetaan topografi detail, pengukuran electrical resistivity tomography (ERT), pengambilan sampel tanah, pengujian geoteknik, dan analisis kestabilan lereng. Metode kesetimbangan batas dengan perhitungan Morgenstern-Price digunakan untuk analisis kestabilan lereng. Daerah studi terdiri dari produk vulkanik berupa tanah residual dan tuf tebal yang bersifat lepas dan kuat geser dalam yang rendah. Hasil analisis ERT menunjukkan adanya perluasan zona jenuh air yang diakibatkan oleh keberadaan kolam ikan. Analisis kestabilan lereng menunjukkan bahwa kemunculan zona jenuh air yang meluas menyebabkan menurunnya nilai faktor keamanan lereng secara signifikan.
\end{abstract}

Naskah masuk : 10 Desember 2019

Naskah direvisi : 9 April 2020

Naskah diterima : 11 April 2020

*Penulis korespondensi.

Email: mochhilmizp@gmail.com
Kata kunci: kestabilan lereng, metode kesetimbangan batas, longsor, ERT.

ABSTRACT - The effect of water saturated zone on slope stability in Weninggalih, Bandung Barat Regency. Shallow landslides in Weninggalih Village resulted in many losses every year. One of the contributing factors is the customs of building a fishpond in the sloping ground without an impermeable liner. Consequently, the seepages from the pond cause the decrease in slope stability. To reduce the risk of loss, a better understanding of the landslide's characteristics and the effect of the fishpond on the stability of the slope is required. The purpose of this study is to determine the level of slope stability and the influence of the fishponds to slope stability in the Weninggalih area. Methods used in this study include geological mapping, detailed topographic mapping, electrical resistivity tomography (ERT), soil sampling, geotechnical laboratory testing, and slope stability analysis. The limit equilibrium method with the MorgensternPrice formula was used for slope stability analysis. The study area is composed of volcanic products consisting residual soil and thick tuff that are loose and having low shear strength. Results of ERT analysis showed the extension of the water saturated zone caused by the presence of fishponds. Analysis of the slope stability shows that the expanding water saturated zone causes a significant decrease in the slope safety factor.

Keywords: slope stability, limit equilibrium method, landslides, ERT. 


\section{PENDAHULUAN}

Indonesia merupakan daerah rawan longsor yang dibuktikan dengan tingginya jumlah kejadian dan korban jiwa akibat kejadian longsor. Sebagian besar korban jiwa terkonsentrasi di Pulau Jawa dengan persentase mencapai $52 \%$ dari korban jiwa di seluruh Indonesia (Cepeda et al., 2010). Pulau Jawa merupakan wilayah dengan kepadatan penduduk tertinggi dan sangat rentan terhadap kejadian longsor, salah satunya yaitu Provinsi Jawa Barat. Berdasarkan inventarisasi data kejadian longsor, 67\% kejadian longsor yang ada di Pulau Jawa terkonsentrasi di Provinsi Jawa Barat (Hadmoko et al., 2017). Berdasarkan data informasi bencana Indonesia dalam satu dekade terakhir (2010-2019), rata-rata kejadian longsor per tahun di Jawa Barat cukup tinggi dengan jumlah mencapai 256 kejadian/tahun (BNPB, 2019). Sehingga dikhawatirkan bahwa jumlah kejadian longsor yang berulang ini dapat menyebabkan pertumbuhan sosial-ekonomi menjadi terhambat karena rusaknya infrastruktur, jalan, jembatan, bangunan, dan lahan pertanian (Teo et al., 2018).

Berdasarkan peta zona kerentanan gerakan tanah Kabupaten Bandung Barat, Kecamatan Sindangkerta termasuk ke dalam zona kerentanan longsor menengah-tinggi (PVMBG, 2018). Selama kurun tahun 2017-2019, telah terjadi tiga kejadian longsor yang mengakibatkan kerugian besar di Kecamatan Sindangkerta. Pada tanggal 27 Februari 2019, di Desa Puncaksari, Kecamatan Sindangkerta terjadi longsor dengan jenis gelinciran bahan rombakan yang mengakibatkan dua rumah rusak berat dan lima rumah terancam rusak. Selanjutnya pada tanggal 5 Maret 2018, di Desa Buninagara, Kecamatan Sindangkerta, terjadi longsor yang mengakibatkan dua korban jiwa, tujuh keluarga terpaksa mengungsi, dan tertutupnya akses jalan oleh timbunan longsor. Kemudian pada tanggal 25 Februari 2017, di Desa Cicangkang Girang, Kecamatan Sindangkerta terjadi longsor gelinciran yang mengakibatkan tiga rumah rusak berat dan tujuh rumah terancam rusak. Selain itu Desa Weninggalih, Kecamatan Sindangkerta yang menjadi daerah studi juga termasuk ke dalam zona intensitas kejadian longsor menengah-tinggi. Dibuktikan dengan tingginya jumlah kejadian longsor di desa Weninggalih, yaitu sekitar 70 kejadian (Gambar 1). Hasil inventarisasi kejadian longsor tersebut menunjukkan bahwa jenis longsor di daerah Weninggalih didominasi oleh luncuran campuran massa tanah dan batuan dengan kedalaman dangkal (Sadisun et al., 2006). Oleh karena itu, mengetahui karakteristik longsor menjadi sangat penting sebagai salah satu upaya mitigasi untuk mengurangi risiko bencana longsor.

Kestabilan lereng merupakan hal kompleks dan memiliki karakteristik yang bersifat lokal, selain itu banyak faktor yang dapat menjadi pemicu terjadinya longsor. Salah satu pemicunya adalah meningkatnya zona jenuh air pada lereng yang akan menyebabkan kestabilan lereng terganggu (Tohari et al., 2017). Salah satu budaya masyarakat di Desa Weninggalih, yaitu membuat kolam ikan pada lereng, diduga menjadi faktor pemicu tersebut (Gambar 2).

Oleh karena itu, penelitian ini bertujuan untuk mengetahui kondisi hidrologi lereng terutama di sekitar kolam ikan dan untuk mengetahui tingkat kestabilan lereng di Desa Weninggalih. Metode yang digunakan diantaranya pemetaan geologi, pengukuran muka air tanah, bor tangan, uji laboratorium geoteknik, pemetaan topografi detail, pengukuran electrical resistivity tomography (ERT) dan analisis kestabilan lereng.

\section{TATANAN GEOLOGI}

Wilayah studi berada pada bagian barat daya Cekungan Bandung, tepatnya di Desa Weninggalih, Kecamatan Sindangkerta, berjarak sekitar $50 \mathrm{~km}$ dari Kota Bandung. Secara morfologi, daerah tersebut merupakan perbukitan bergelombang dengan ketinggian \pm 1.000 hingga 1.150 meter dari permukaan laut.

Berdasarkan geologi regionalnya, zona ini mempunyai ciri geologi berupa litologi batuan endapan laut berumur Tersier dan endapan produk vulkanik yang memperlihatkan adanya patahan mendatar yang berarah hampir baratlauttenggara (Gambar 3). Stratigrafi daerah ini terdiri atas batuan yang tertua berupa endapan sedimen, yaitu Anggota Sindangkerta Formasi Cimandiri (Tmcs) yang terdiri dari tuf batuapung, batupasir tuf dan breksi tuf. Selanjutnya, secara menjari atau membaji diendapkan Formasi Cimandiri (Tmc), berupa perselingan batulempung dan batulanau kelabu muda, dan batupasir setempat gampingan. Di atasnya secara tidak selaras diendapkan batuan vulkanik dari Formasi Beser 

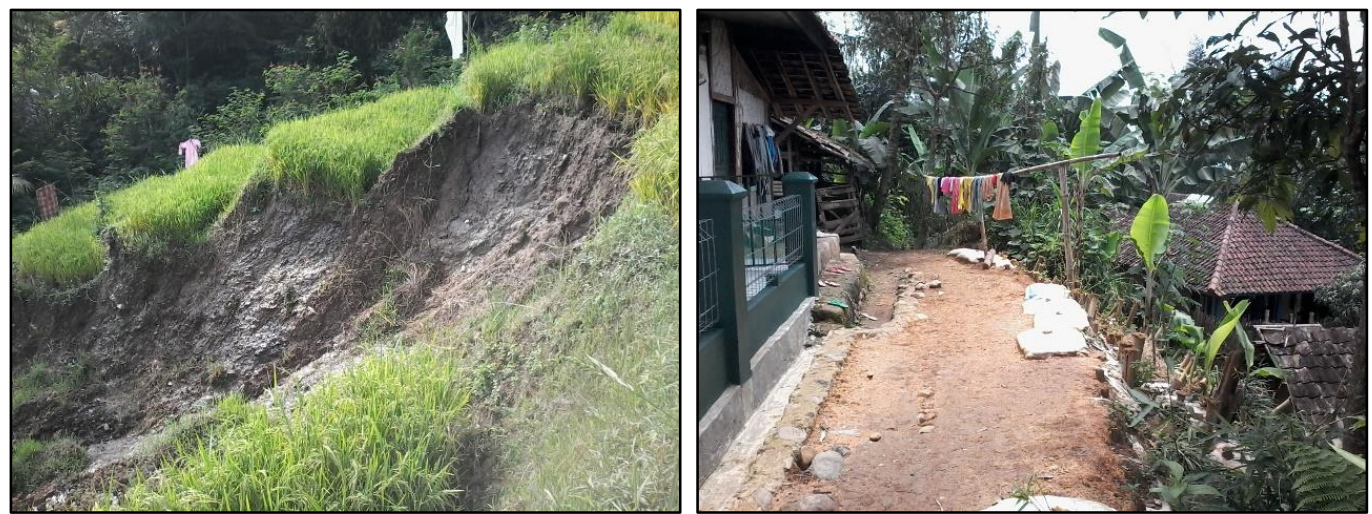

Gambar 1. Rusaknya lahan pertanian dan bergesernya tanah di sekitar pemukiman disebabkan oleh pergerakan tanah di Desa Weninggalih, Kecamatan Sindangkerta.
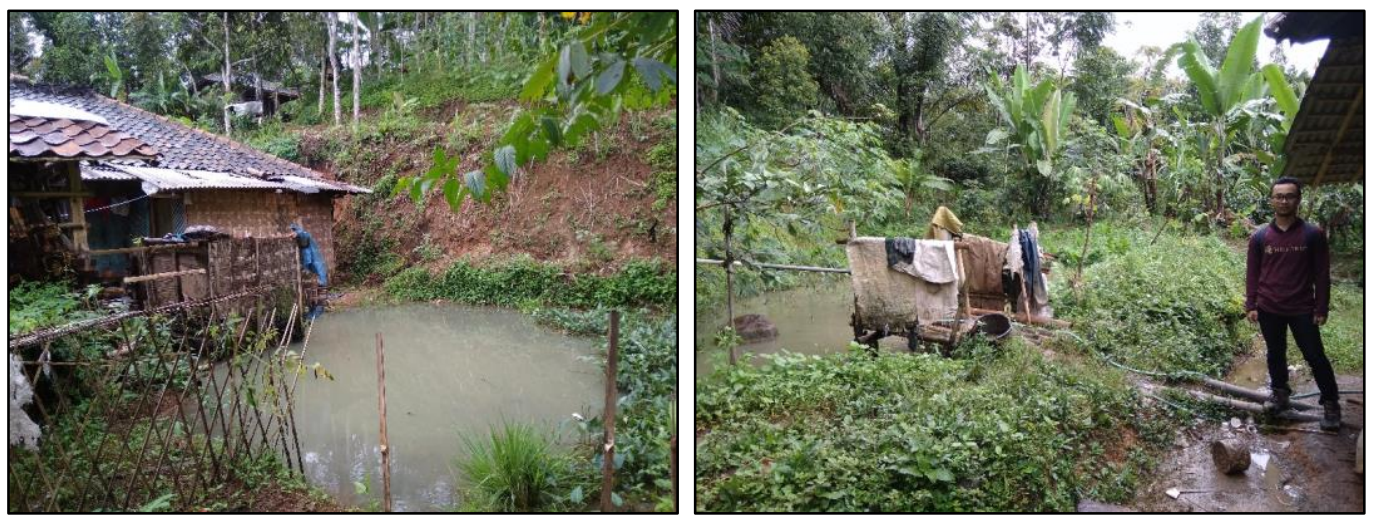

Gambar 2. Keberadaan kolam yang dibuat oleh warga untuk keperluan sehari-hari.

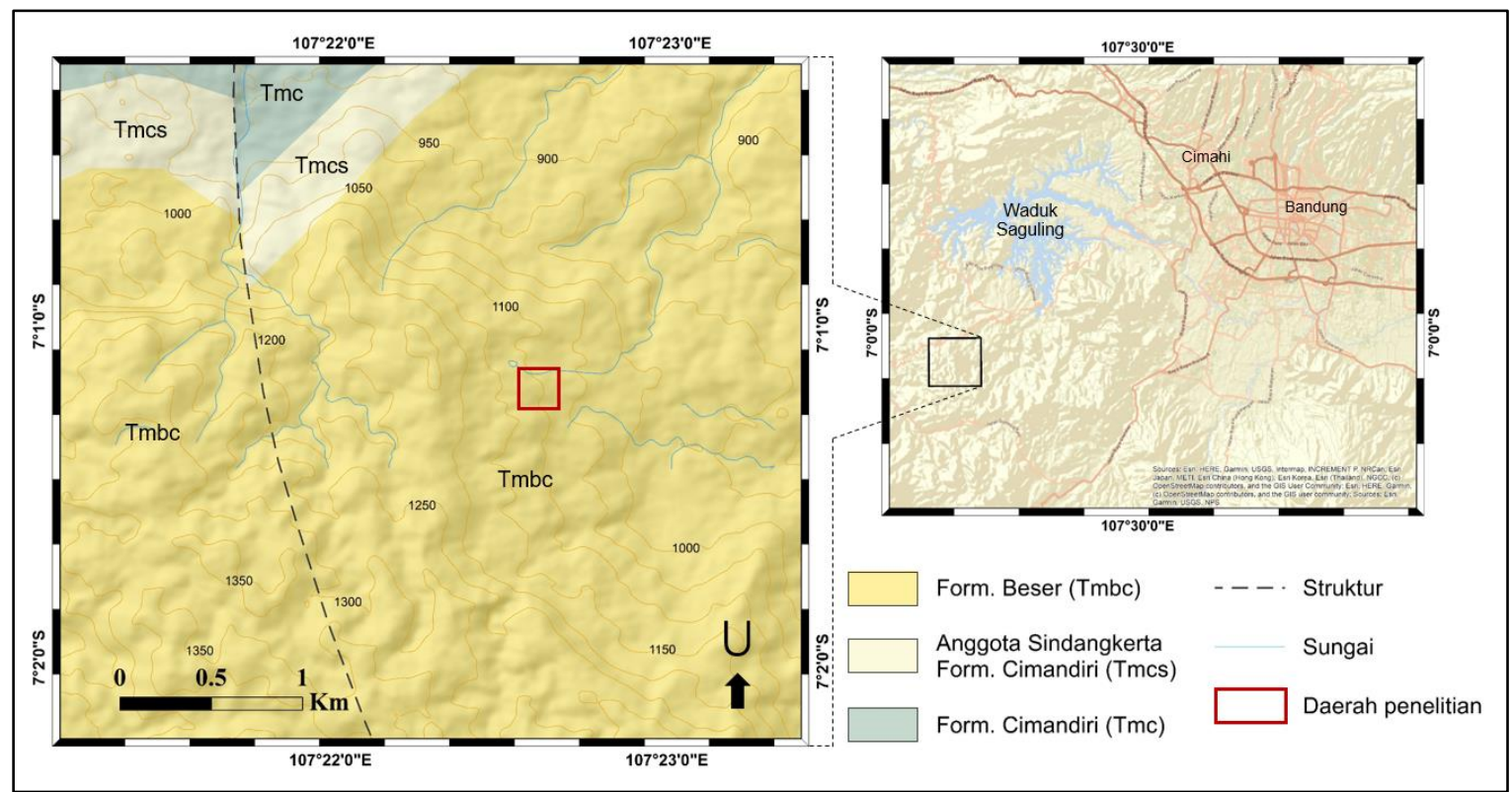

Gambar 3. Geologi regional daerah penelitian dan sekitarnya (Koesmono et al., 1996).

(Tmbc) terdiri dari breksi andesit, breksi tuf, tuf dan batulempung endapan vulkanik muda ini mempunyai sifat koheren, berpori, dan mudah lulus air (Koesmono et al., 1996).
Pemetaan geologi permukaan detail, empat titik bor tangan, dan pengukuran ERT pada dua lintasan dilakukan untuk mengetahui litologi bawah permukaan. Pemetaan geologi permukaan 
menunjukkan bahwa berdasarkan singkapan yang ada daerah studi terdiri dari tanah residual, tuf, dan breksi andesit (Gambar 4). Kemudian pengukuran ERT dan bor tangan dilakukan untuk mengetahui ketebalan dan pesebaran litologi tersebut. ERT dilakukan pada dua lintasan yang searah dengan kemiringan lereng. Gambar 4 menunjukkan lokasi dari empat titik bor tangan dan dua lintasan $E R T$ tersebut.

Berdasarkan data curah hujan di stasiun Bendungan Saguling, jumlah rata-rata curah hujan tahunan cukup tinggi, yaitu sebesar 1.937 $\mathrm{mm}$. Curah hujan tinggi tersebut cenderung terjadi selama bulan Oktober hingga April. Sedangkan intensitas hujan bulanan berkisar antara 135-236 mm/bulan dengan rata-rata curah hujan sebesar $12-15 \mathrm{~mm} /$ hari.

\section{METODE}

Metode penelitian diawali dengan pemetaan topografi detail menggunakan interval kontur 1 meter. Kemudian dilanjutkan dengan pemetaan geologi permukaan, pengukuran ERT, dan pengeboran tangan pada empat titik hingga kedalaman \pm 2 meter yang untuk mendapatkan profil tanah dan batuan bawah permukaan.

$E R T$ adalah salah satu metode geofisika yang digunakan untuk mengetahui kondisi bawah permukaan dengan cara menginjeksikan arus listrik dan memanfaatkan perbedaan nilai tahanan jenis batuan dalam menghantarkan listrik (Reynolds, 1998). Salah satu aplikasi ERT adalah untuk menganalisis pola spasial di bawah permukaan, seperti mengidentifikasi lokasi zona kegagalan, stratifikasi litologi, dan mendeteksi tingkat kejenuhan air di bawah permukaan (Bellanova et al., 2018; Crawford et al., 2018).

Alat yang digunakan untuk pengukuran ERT yaitu automatic resistivity system (ARES) $2 D$ multi-channel, dengan 48 elektroda, jarak antar elektroda $1,5 \mathrm{~m}$, menggunakan konfigurasi Wenner, dan lintasan sepanjang \pm 72 meter.

Konfigurasi Wenner digunakan karena memiliki keteraturan dalam hal perpindahan posisi elektroda yang menjadi keunggulan dalam pengukuran multi-channel, yaitu hanya dengan mengubah koefisien a (jarak antar elektroda)

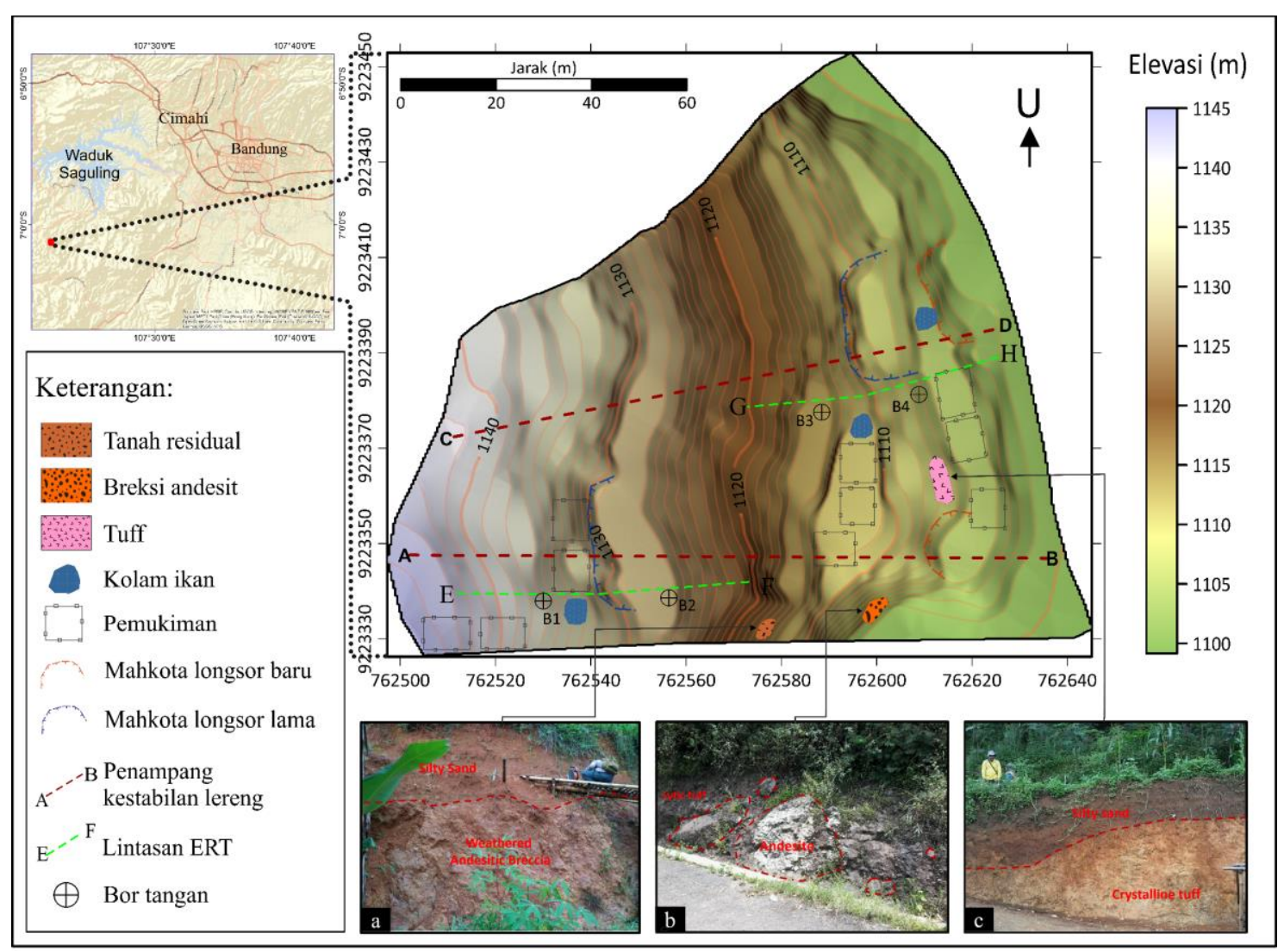

Gambar 4. Topografi detail dan persebaran gawir, singkapan, bor tangan, dan pemukiman. 


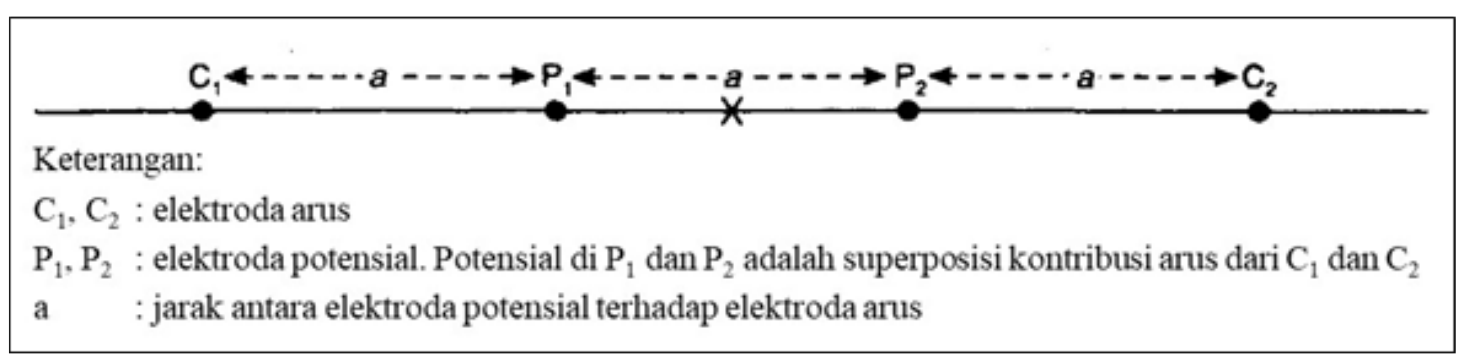

Gambar 5. Konfigurasi elektroda Wenner (Reynolds,1997)

untuk mendapatkan sebaran data ke arah vertikal dan menggeser konfigurasi tersebut untuk mendapatkan sebaran ke arah horizontal (Gambar 5) (Reynolds, 1998).

Jarak antar elektroda yang dekat ini $(1,5 \mathrm{~m})$ dipilih karena efektif digunakan untuk mengkarakterisasi diskontinuitas horizontal, terutama untuk menyelidiki zona kegagalan dangkal $(<10 \mathrm{~m})$ berdasarkan sensitivitas struktur konfigurasi horizontalnya (Bellanova et al., 2018). Konfigurasi Wenner untuk ERT dipilih selain karena susunan elektrode yang sama sehingga memudahkan dalam penggunaan metode multi-channel, juga karena konfigurasi dengan jarak elektrode yang dekat tersebut efektif untuk pemetaan bawah permukaan yang dangkal, hal ini menjadi pertimbangan karena kedalaman longsoran di daerah ini umumnya relatif dangkal, yaitu kurang dari sepuluh meter (Kartiko et al., 2016; Sadisun et al., 2006). Pengukuran ERT dilakukan pada pertengahan musim hujan. Proses pemodelan inversi dari hasil ERT dilakukan dengan menggunakan perangkat lunak $A G I$ Earthimager 2D (AGI, 2002). Perangkat lunak ini dipilih karena hasil pemodelan yang dihasilkan sudah bagus.

Sampel tanah diambil dari tiga lokasi untuk kemudian dilakukan pengujian di lab geoteknik. Pengujian sifat fisik dan mekanik pada sampel tanah tak terganggu dilakukan untuk mendapatkan properti tanah yang meliputi berat jenis, ukuran butir, kadar air, dan uji geser langsung berdasarkan ASTM D7263-09, ASTM D422-63, ASTM D2216-98 dan ASTM D308004. Kedalaman muka air tanah di lokasi studi berkisar antara 8-10 meter (BNPB, 2017). Analisis kestabilan lereng kemudian dilakukan dengan menggunakan data topografi, properti tanah, dan kedalaman muka air tanah tersebut. Analisis kestabilan lereng dilakukan secara tegak lurus pada lereng dan persebaran mahkota longsor untuk mendapatkan kondisi kestabilan lereng sepanjang lintasan dan dilakukan menggunakan metode kesetimbangan batas dengan perhitungan Morgenstern-Price (Morgenstern dan Price, 1965).

Dalam kasus analisis kestabilan lereng umum digunakan asumsi bahwa bidang gelincirnya berbentuk melingkar yang dilakukan agar perhitungan komputasi menjadi lebih sederhana. Morgenstern dan Price (1965) mencoba mengembangkan metode kesetimbangan batas dari pengembangan yang telah dilakukan beberapa peneliti sebelumnya, diantaranya oleh Janbu (1957; 1954), Kenney (1956), dan Janbu et al. (1956). Namun, dari semua metode yang telah dikembangkan tersebut hanya memperhitungkan kesetimbangan gaya dan belum memperhitungkan kesetimbangan momen seperti yang diharapkan. Selain itu, hasil perhitungan komputasi menggunakan metode-metode sebelumnya tersebut masih terdapat kesalahan/error. Hal ini menjadi alasan digunakannya metode dari Morgenstern dan Price (1965), yaitu karena semua kesetimbangan sudah diperhitungkan, baik itu kesetimbangan gaya maupun kesetimbangan momen (Persamaan 1). Gambar 6 mengilustrasikan gaya-gaya yang bekerja pada suatu elemen dan tiap irisan dalam analisis kestabilan lereng pada persamaan berikut:

$F K=\frac{\text { Penjumlahan gaya penahan }}{\text { Penjumlahan gaya pendorong }}$
$F K=\frac{c^{\prime} d x \sec \alpha+d N^{\prime} \tan \phi^{\prime}}{d E^{\prime} \cos \alpha+d P_{w} \cos \alpha-d X \sin \alpha+d W \sin \alpha}$

dimana $F K$ adalah faktor keamanan, $c^{\prime}$ adalah kohesi $(\mathrm{Pa}), x$ adalah panjang terhadap sumbu-x (m), $y$ adalah panjang terhadap sumbuy $(\mathrm{m}), N^{\prime}$ adalah gaya normal $(\mathrm{N}), \phi^{\prime}$ adalah sudut geser dalam $\left({ }^{\circ}\right), \alpha$ adalah sudut irisan 

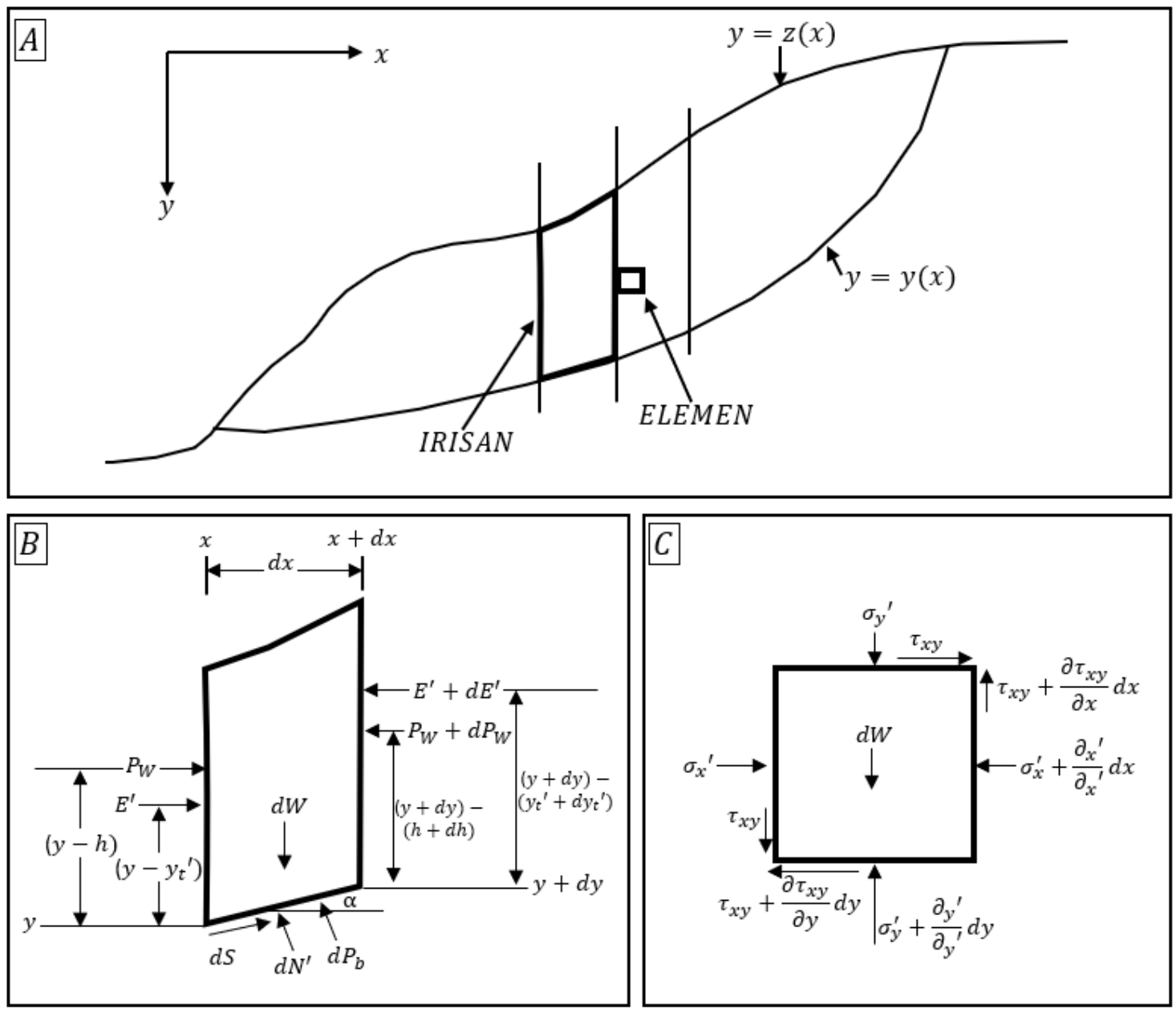

Gambar 6. a). Ilustrasi salah satu elemen pada dua irisan, b). Ilustrasi gaya-gaya yang bekerja pada suatu irisan, c). Ilustrasi tegangan efektif yang bekerja pada suatu elemen (gambar ulang dari Morgenstern dan Price, 1965).

terhadap bidang datar $\left(^{\circ}\right), E^{\prime}$ adalah tegangan efektif pada sisi samping irisan $(\mathrm{Pa}), P_{w}$ adalah resultan tekanan fluida/air pada sisi samping irisan $(\mathrm{Pa}), P_{b}$ adalah tekanan fluida/air pada dasar irisan $(\mathrm{Pa}), W$ adalah berat tiap irisan $(\mathrm{N})$, dan $X s$ adalah gaya gesek vertikal pada sisi samping irisan $(\mathrm{Pa})$.

Hasil perhitungan yang diperoleh dari analisis tersebut berupa nilai Faktor Keamanan (FK). Nilai tersebut adalah perbandingan dari gaya penahan terhadap gaya penggerak pada lereng. Semakin rendah nilai FK-nya maka semakin tidak stabil kondisi lereng, begitupun sebaliknya. Nilai FK tersebut nanti

Hasil perhitungan yang diperoleh dari analisis tersebut berupa nilai Faktor Keamanan (FK). Nilai tersebut adalah perbandingan dari gaya penahan terhadap gaya penggerak pada lereng. Semakin rendah nilai FK-nya maka semakin tidak stabil kondisi lereng, begitupun sebaliknya. Nilai FK tersebut nanti diklasifikasikan terhadap kelas kejadian keruntuhan lereng (Tabel 1). Perhitungan analisis kestabilan lereng ini dilakukan secara komputasi menggunakan perangkat lunak Slide versi 6.005 (Rocscience, 2010). Perangkat lunak tersebut merupakan program analisis kestabilan lereng untuk mengevaluasi faktor keamanan atau probabilitas terjadinya keruntuhan dengan menggunakan metode kesetimbangan batas secara dua dimensi. Perangkat lunak ini dipilih karena kemudahan dalam pembuatan model, kemampuan dalam melakukan berbagai analisis dengan cepat, dan tampilan yang baik, sehingga memudahkan dalam penggunaan dan penyajian hasil analisis. 


\section{HASIL}

\section{Topografi, Singkapan, Bor Tangan, dan ERT}

Topografi detail menunjukkan bentukan tapal kuda akibat adanya longsor (Gambar 4). Hasil pemetaan geologi menunjukkan bahwa daerah penelitian tersusun oleh tanah residual, tuf, dan breksi andesit. Data dari empat titik bor tangan dengan kedalaman $\pm 2 \mathrm{~m}$ menunjukkan bahwa pada kedalaman $0-0,5 \mathrm{~m}$ litologi berupa tanah residual dan pada kedalaman 0,5-2 m berupa tuf.

Hasil interpretasi data ERT dari dua lintasan searah lereng mempertegas bahwa litologi pada lintasan tersebut relatif homogen berupa tuf tidak jenuh air yang ditunjukkan dengan persebaran nilai tahanan jenis yang homogen bernilai tahanan jenis 30-200 $\mathrm{Ohm} \cdot \mathrm{m}$ (warna hijau). Namun terdapat beberapa titik yang menunjukkan tahanan jenis tinggi yang berkorelasi dengan keberadaan bongkahbongkah andesit (warna merah) (Gambar 7). Tabel 2 menunjukkan kedekatan nilai tahanan jenis litologi di daerah penelitian terhadap nilai tahanan jenis pada literatur (Reynolds, 1998).

Nilai tahanan jenis yang rendah bernilai 3-30 $\mathrm{Ohm} \cdot \mathrm{m}$ tersebar di tiga lokasi. Pertama di dekat permukaan, kedua di sekitar kolam ikan, dan ketiga pada kedalaman lebih dari enam meter. Berdasarkan data lapangan, semua lokasi tersebut tersusun oleh litologi berupa tuf yang sama. Pada lokasi pertama, nilai tahanan jenis dekat permukaan memiliki korelasi dengan permukaan tanah jenuh akibat infiltrasi hujan, dikarenakan pengambilan data yang dilakukan pada pertengahan musim hujan. Lokasi kedua untuk tahanan jenis rendah memiliki korelasi dengan keberadaan kolam ikan yang diduga mengakibatkan zona jenuh air menjadi lebih luas yang ditandai dengan kotak merah pada Gambar 7. Sedangkan lokasi tiga pada kedalaman lebih dari enam meter memiliki korelasi dengan kedalaman muka air tanah pada sumur warga di sekitar daerah tersebut. Data keseluruhan, baik itu data singkapan, bor tangan, maupun penampang ERT, menunjukkan bahwa daerah penelitian tersusun oleh tanah residual dengan ketebalan $0,5-1 \mathrm{~m}$, tuf relatif tebal, dan di beberapa titik terdapat bongkah andesit.

\section{Uji Laboratorium}

Sampel tanah diambil dari tiga lokasi yang berbeda untuk diuji di lab geoteknik. Pengujian sifat fisik dan mekanik pada tanah tak terganggu

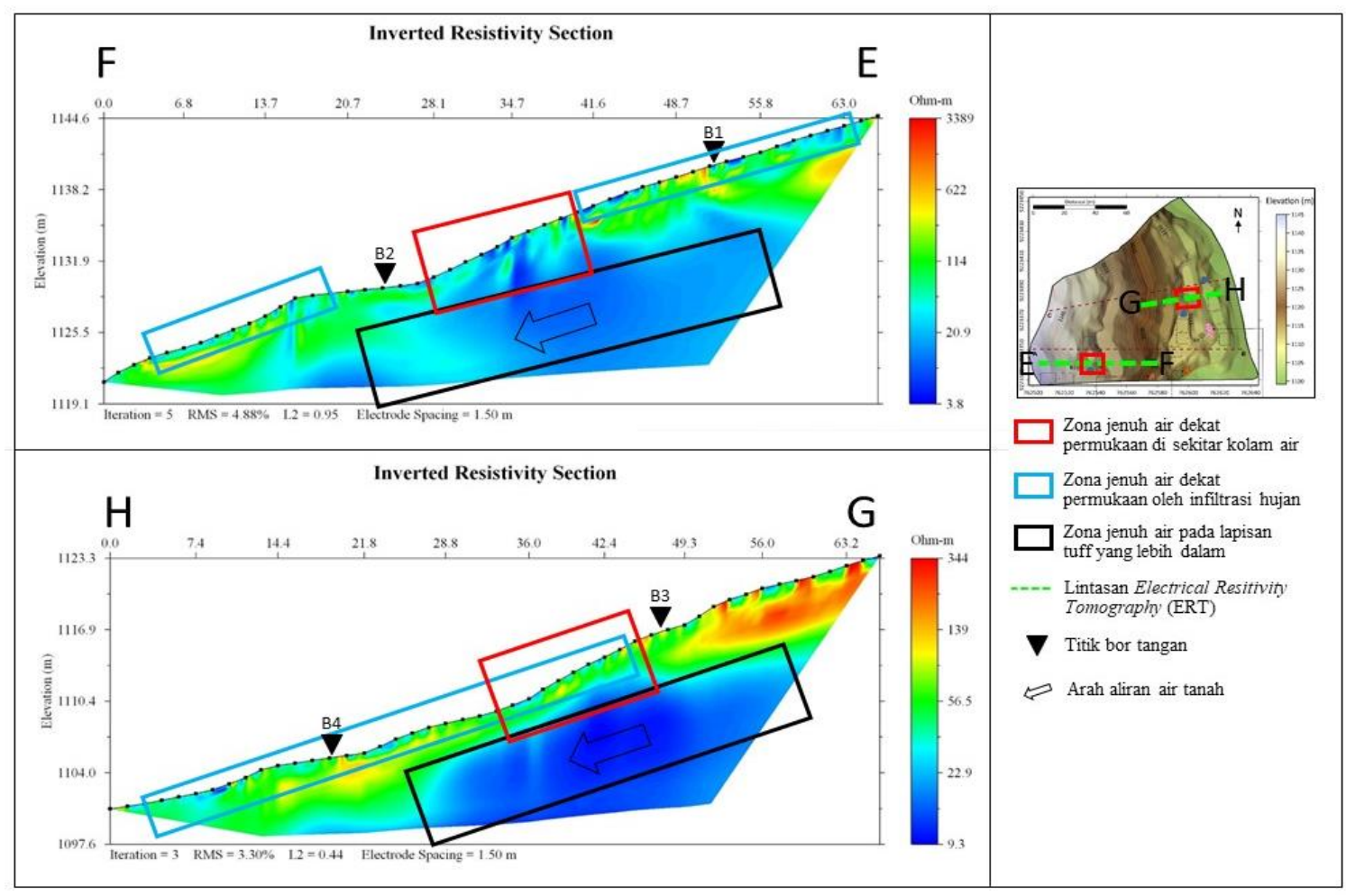

Gambar 7. Persebaran nilai tahanan jenis ERT bawah permukaan pada penampang EF dan GH. 
dilakukan untuk mendapatkan properti tanah yang meliputi berat jenis, ukuran butir, kadar air, dan uji geser langsung berdasarkan ASTM D7263-09, ASTM D422-63, ASTM D2216-98 dan ASTM D3080-04. Hasil dari pengujian sifat fisik dan mekanik tanah dapat dilihat pada Tabel 3.

Tabel 1. Hubungan antara faktor keamanan terhadap kejadian keruntuhan lereng (Bowles, 1979)

\begin{tabular}{cl}
\hline FK & \multicolumn{1}{c}{ Kejadian } \\
\hline FK $<1,07$ & $\begin{array}{l}\text { Keruntuhan umum } \\
\text { terjadi/tidak stabil }\end{array}$ \\
$1,07<\mathrm{FK}<1,25$ & Keruntuhan terjadi/kritis \\
FK $>1,25$ & $\begin{array}{l}\text { Keruntuhan hampir tidak } \\
\text { pernah terjadi/stabil }\end{array}$ \\
\hline
\end{tabular}

Tabel 2. Nilai tahanan jenis beberapa litologi di daerah penelitian

\begin{tabular}{lcc}
\hline \multicolumn{1}{c}{ Litologi } & $\begin{array}{c}\text { Daerah } \\
\text { penelitian } \\
\text { Ohm·m }\end{array}$ & $\begin{array}{c}\text { Reynolds } \\
\mathbf{( 1 9 8 8 )} \\
\mathbf{O h m} \cdot \mathbf{m}\end{array}$ \\
\hline $\begin{array}{l}\text { Tanah residual } \\
\text { (jenuh air) }\end{array}$ & $3-30$ & $15-30$ \\
$\begin{array}{l}\text { Tuf (tidak jenuh } \\
\text { air) }\end{array}$ & $30-100$ & $30-100$ \\
Tuf (jenuh air) & $3-30$ & $15-30$ \\
Breksi andesit & $>100$ & $100-1.400$ \\
\hline
\end{tabular}

Tabel 3. Hasil uji laboratorium

\begin{tabular}{lcc}
\hline \multicolumn{1}{c}{ Properti Tanah } & $\begin{array}{c}\text { Tanah } \\
\text { Residual }\end{array}$ & Tuf \\
\hline Berat jenis $\left(\mathrm{kN} / \mathrm{m}^{3}\right)$ & 17,80 & 18,42 \\
Berat jenis jenuh $\left(\mathrm{kN} / \mathrm{m}^{3}\right)$ & 21,90 & 21,80 \\
Kohesi, $\mathrm{c}\left(\mathrm{kN} / \mathrm{m}^{2}\right)$ & 12,21 & 14,50 \\
Sudut geser dalam, $\varphi\left({ }^{\circ}\right)$ & 25,85 & 26,32 \\
\hline
\end{tabular}

\section{Analisis Kestabilan Lereng}

Analisis kestabilan lereng dilakukan secara tegak lurus lereng dan pada lokasi yang terindikasi mengalami longsoran, yaitu pada penampang selatan $(\mathrm{AB})$ dan penampang utara $(\mathrm{CD})$ (Gambar 4). Analisis kestabilan lereng menggunakan dua skenario dilakukan masing-masing pada penampang $\mathrm{AB}$ dan $\mathrm{CD}$. Skenario pertama menggunakan asumsi bahwa tidak ada kolam air yang menyebabkan zona jenuh air meluas, terutama di sekitar kolam air dan muka air tanah $\pm 6 \mathrm{~m}$ sesuai data lapangan. Skenario kedua menggunakan kondisi zona jenuh air sesuai dengan kondisi sebenarnya, yaitu berdasarkan data ERT yang didapatkan (Gambar 7). Zona jenuh air pada kondisi kedua lebih luas karena ada pengaruh dari infiltrasi air dari kolam di atasnya.

Gambar 8a dan 8b menunjukkan kondisi kestabilan lereng pada penampang $\mathrm{AB}$ di bagian selatan. Gambar 8a adalah kondisi kestabilan lereng yang dimodelkan menggunakan skenario pertama, hasilnya menunjukkan bahwa FK minimum yang dihasilkan sebesar 1,335 (kondisi stabil). Sedangkan Gambar 8b menggunakan skenario kedua, FK minimum yang dihasilkan menurun secara signifikan menjadi 0,978 (kondisi tidak stabil).

Gambar 9a dan 9b menggambarkan kondisi kestabilan lereng pada penampang CD di bagian utara. Gambar 9a adalah penampang hasil analisis kestabilan lereng yang menggunakan skenario pertama, hasilnya menunjukkan FK minimum sebesar 1,379 (kondisi stabil). Pada skenario kedua (Gambar 9b) FK minimum turun secara signifikan menjadi 1,151 (kondisi kritis).

\section{DISKUSI}

Hasil electrical resistivity tomography (ERT) menunjukkan kondisi hidrologi yang diwakili oleh resistivitas rendah berwarna biru dengan nilai tahanan jenis 3-30 Ohm·m (Gambar 7). Nilai tahanan jenis rendah tersebar di beberapa lokasi, diantaranya di dekat permukaan pada kedalaman 00,5 $\mathrm{m}$ yang diakibatkan oleh infiltrasi air hujan, pada kedalaman $>6 \mathrm{~m}$ yang mewakili kedalaman muka air tanah, dan di sekitar kolam air. Hasil ERT tersebut menunjukkan bahwa keberadaan kolam air menyebabkan tingkat kejenuhan air pada lapisan tanah yang lebih dalam meningkat.

Hasil analisis kestabilan lereng menunjukkan bahwa kondisi hidrologi dengan keberadaan kolam air yang menyebabkan zona jenuh air meluas, memiliki pengaruh besar terhadap penurunan nilai FK secara signifikan. Hal itu disebabkan karena semakin meluasnya zona jenuh air pada tubuh lereng menyebabkan properti material yang jenuh air semakin menurun. Adanya air yang mengisi pori akan menyebabkan beberapa hal yang dapat menurunkan kestabilan lereng, diantaranya yaitu meningkatnya berat jenis tanah serta menurunnya nilai kohesi dan sudut geser dalam. 


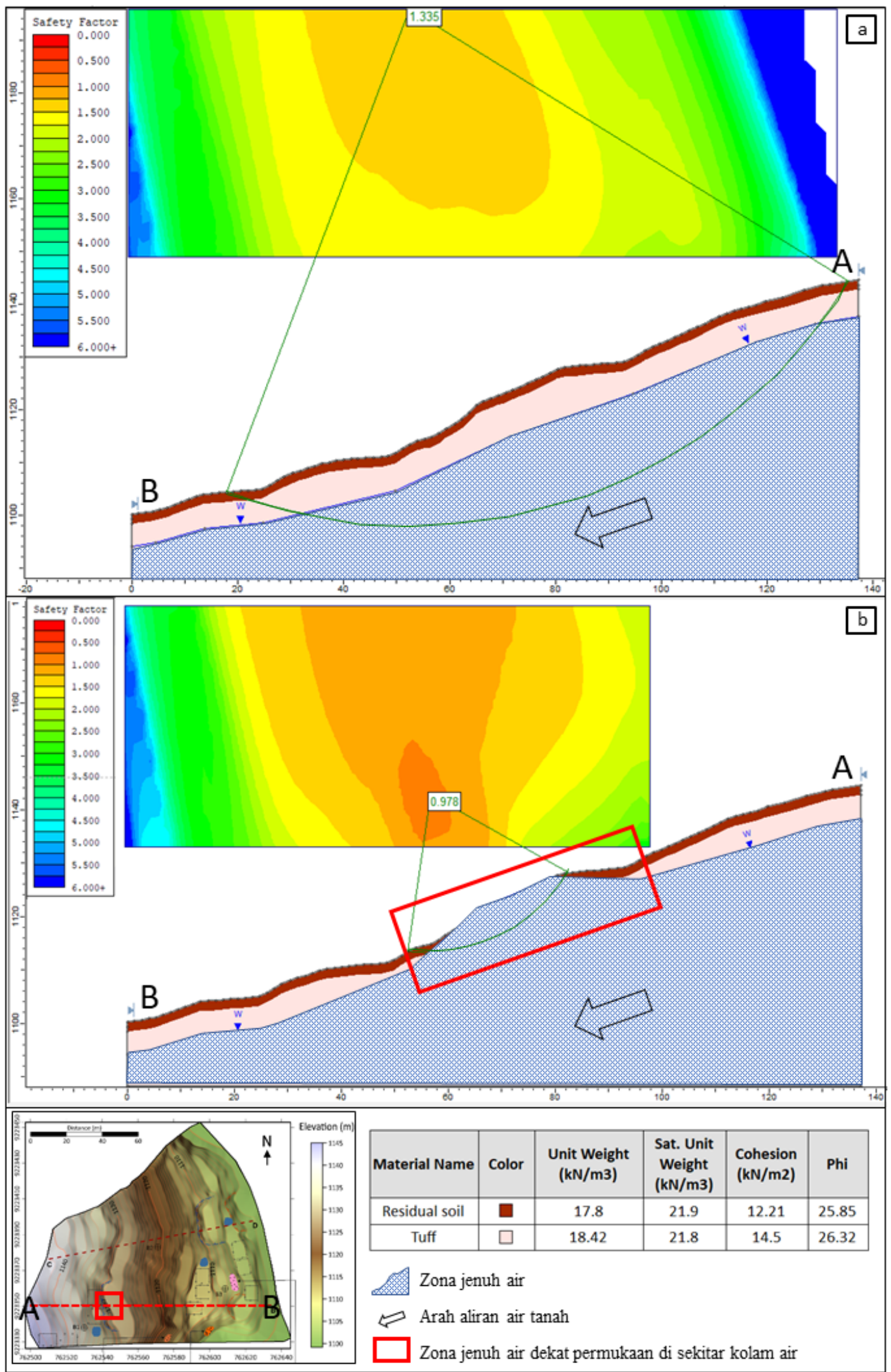

Gambar 8. a). Analisis kestabilan lereng lintasan AB menggunakan skenario satu, b). Analisis kestabilan lereng lintasan $\mathrm{AB}$ menggunakan skenario kedua. 


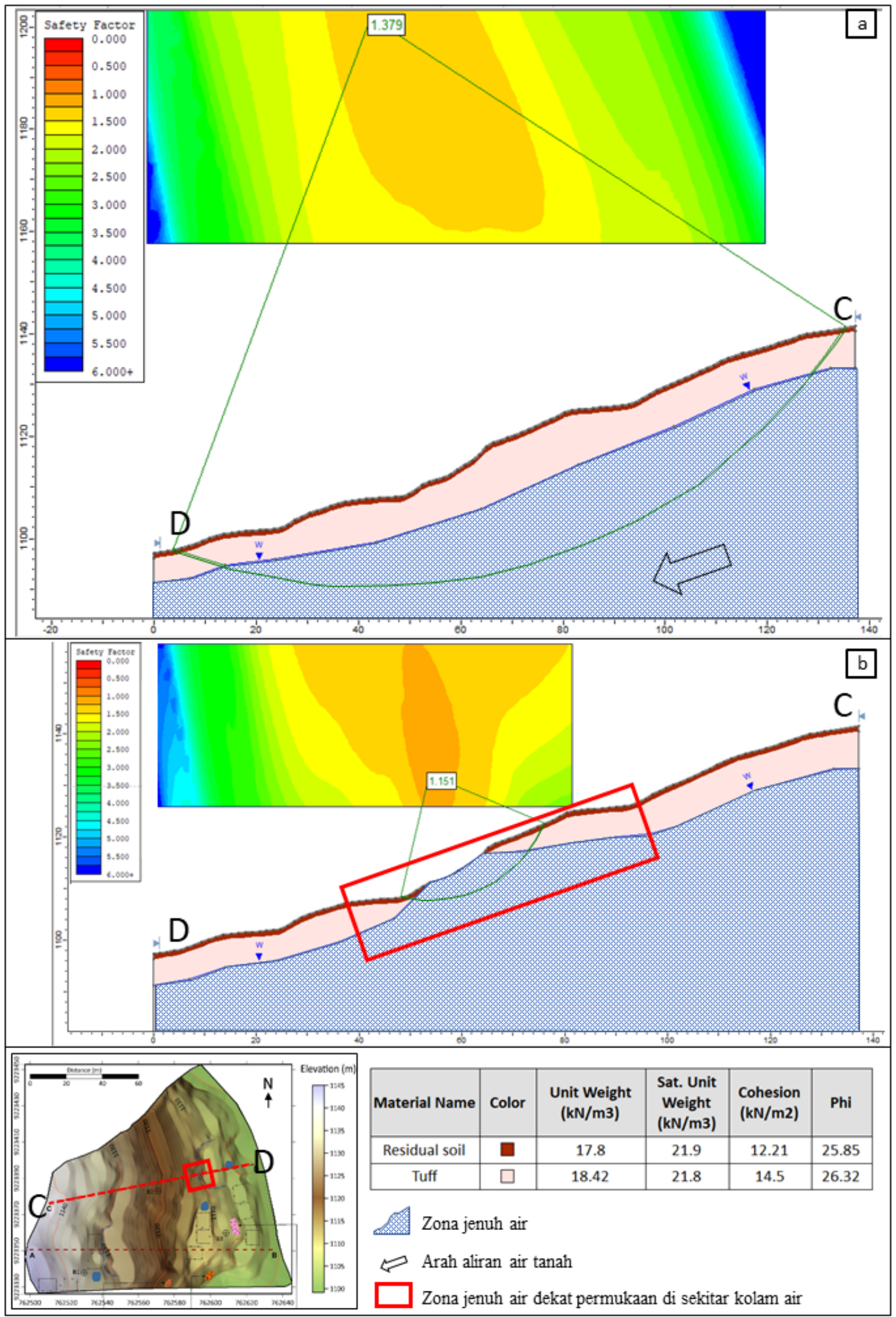

Gambar 9. a). Analisis kestabilan lereng lintasan CD menggunakan skenario satu, b). Analisis kestabilan lereng lintasan CD menggunakan skenario kedua. 
Faktor hidrologi menjadi faktor yang patut diperhatikan untuk menjaga lereng tetap dalam kondisi stabil (Tohari et al., 2017). Oleh karena itu, menjaga tingkat kejenuhan air menjadi sangat penting dilakukan untuk menjaga kestabilan lereng. Hal yang dapat dilakukan diantaranya dengan tidak membuat kolam air tanpa dibatasi dengan lapisan impermeable atau dengan cara menurunkan muka air tanah, salah satu caranya yaitu dengan menggunakan metode siphon (Syahbana et al., 2014).

\section{KESIMPULAN}

Secara tatanan geologi daerah studi tersusun oleh tanah residual, tuf dan breksi andesit. Hasil ERT menunjukkan kondisi hidrologi dan persebaran zona jenuh air di sekitar kolam air. Berdasarkan analisis kestabilan lereng, meluasnya zona jenuh air yang diakibatkan oleh keberadaan kolam air berkontribusi terhadap menurunnya nilai FK secara signifikan.

\section{UCAPAN TERIMAKASIH}

Penulis mengucapkan terima kasih kepada rekanrekan yang telah membantu penulisan makalah ini. Terima kasih kepada rekan-rekan Laboratorium Geologi Teknik - ITB dan seluruh redaksi Jurnal Riset Geologi dan Pertambangan serta rekan-rekan yang telah membantu sehingga tulisan ini dapat diselesaikan. Penulis berterima kasih kepada reviewer yang telah memberikan masukan dalam perbaikan naskah tulisan ini.

\section{DAFTAR PUSTAKA}

AGI, 2002. EarthImager 2D Resistivity and IP Invesion. Advance Geosciences. Austin, Texas 78726.

ASTM D2216 - 98, 1998. D2216 - 98 Standard

Test Method for Laboratory

Determination of Water (Moisture)

Content of Soil and Rock by Mass. https://doi.org/10.1520/D2216-19

ASTM D3080 - 04, 2004. D3080 - 04 Direct Shear Test of Soils Under Consolidated Drained Conditions 1-9. https://doi.org/10.1520/D3080-04

ASTM D422 - 63, 2007. D422 - 63 Standard Test Method for Particle-Size Analysis of Soils. Astm D422-63, 1-8. https://doi.org/10.1520/D0422-

\section{R07E01.2}

ASTM D7263 - 09, 2009. D7263 - 09 Standard

Test Methods for Laboratory Determination of Density (Unit Weight) of Soil Specimens. https://doi.org/10.1520/D726309R18E02

Bellanova, J., Calamita, G., Giocoli, A., Luongo, R., Macchiato, M., Perrone, A., Uhlemann, S., Piscitelli, S., 2018. Electrical Resistivity Imaging for the Characterization of the Montaguto Landslide (Southern Italy). Eng. Geol. 243, 272-281. https://doi.org/10.1016/j.enggeo.2018.0 7.014

BNPB, 2019. Data Informasi Bencana Indonesia (DIBI) [WWW Document]. URL http://www.bnpb.cloud/dibi/laporan5 (diakses 11.7.19).

BNPB, 2017. Atlas Bencana Indonesia 2016.

Bowles, J.E., 1979. Physical and Geotechnical Properties of Soils, Internatio. ed. McGraw-Hill Book Company, New York, N.Y., U.S.A.

Cepeda, J., Smebye, H., Vangelsten, B., Nadim, F., Muslim, D., 2010. Landslide Risk in Indonesia. Glob. Assess. Rep. Disaster Risk Reduct. 20.

Crawford, M.M., Bryson, L.S., Woolery, E.W., Wang, Z., 2018. Using 2-D Electrical Resistivity Imaging for Joint Geophysical and Geotechnical Characterization of Shallow Landslides. J. Appl. Geophys. 157, 37-46. https://doi.org/10.1016/j.jappgeo.2018.0 6.009

Hadmoko, D.S., Lavigne, F., Sartohadi, J., Gomez, C., Daryono, 2017. SpatioTemporal Distribution of Landslides in Java and the Triggering Factors. Forum Geogr. 31, 1. https://doi.org/10.23917/forgeo.v31i1.3 790

Janbu, N., 1954. Application of Composite Slip Surfaces for Stability Analysis, in: Proceeding European Conferrence on Stability of Earth Slopes, Stockholm. 
hal. 43-49.

Janbu, N., 1957. Earth Pressure and Bearing Capacity by Generalized Procedure of Slices, in: Proceeding Fourth International Conferrence Soil Mechanics. hal. 207-212.

Janbu, N., Bjerrum, L., Kjaernsli, B., 1956. Soil Mechanics Applied to Some Engineering Problems. Nor. Geotech. Inst. 16.

Kartiko, R.D., Sadisun, I.A., Tohari, A., Sumintadiredja, P., 2016. Laboratory Scale of Rainfall's Pattern and Threshold in Volcanic Soil Slope Failure, in: AIP Conference Proceedings. https://doi.org/10.1063/1.4947406

Kenney, T.C., 1956. An Examination of the Methods of Calculating the Stability of Slopes. M.Sc. Thesis, University of London.

Koesmono, M., Kusnama, Suwarna, N., 1996. Peta Geologi Lembar Sindangbarang dan Bandarwaru, Jawa. 2nd Edition.

Morgenstern, N.R., Price, V.E., 1965. The Analysis of the Stability of General Slip Surfaces. Geotechnique 15, 79-93. https://doi.org/10.1680/geot.1965.15.1.7 9

PVMBG, 2018. Peta Zona Kerentanan Gerakan Tanah Kabupaten Bandung Barat, Provinsi Jawa Barat [WWW Document]. URL http://vsi.esdm.go.id/gallery/picture.php ?/109/category/15 (diakses 1.5.19).

Reynolds, J.M., 1998. An Introduction to Applied and Environmental Geophysics. John
Wiley \& Sons, Baffins Lane, Chichester, West Sussex PO19 IUD, England.

Rocscience, 2010. Slide Version 6.005.

Sadisun, I.A., Kartiko, R.D., Adianto, A.Y., 2006. Landslide Frequency Analysis in a Mountainous Area of Weninggalih , West Java , Indonesia - A Technical Note, in: PIT IAGI RIAU 2006. https://doi.org/10.13140/2.1.3584.0322

Syahbana, A.J., Tohari, A., Sugianti, K., Aji S, N., Wibowo, S., Winduhutomo, S., 2014. Rekayasa Hidraulika Kestabilan Lereng Dengan Sistem Siphon: Studi Kasus Di Daerah Karangsambung, Jawa Tengah. J. Ris. Geol. dan Pertamb. 24, 103. https://doi.org/10.14203/risetgeotam201 4.v24.87

Teo, M., Goonetilleke, A., Ahankoob, A., Deilami, K., Lawie, M., 2018. Disaster Awareness and Information Seeking Behaviour Among Residents from Low Socio-economic Backgrounds. Int. J. Disaster Risk Reduct. 31, 1121-1131. https://doi.org/10.1016/j.ijdrr.2018.09.0 08

Tohari, A., Koizumi, K., Syahbana, A.J., Oda, K., 2017. Understanding of Landslide Movement at Bumi Waluya Railway Station, Garut, Indonesia. Conference proceedings WLF: Advancing Culture of Living with Landslides, vol 2, Advances in Landslide Science, Ed. Mikos, M., Tiwari, B., Yin, Y., and Sassa, K., p 319-328. https://doi.org/10.1007/978-3-31953498-5 